\title{
Theoretical Platform of ICT for Teaching Adults
}

\author{
Larisa Yu. Aysner, \\ Svetlana V. Bershadskaya and Olga V. Bogdan* \\ Krasnoyarsk State Agrarian University \\ 117 Lenin Str., Krasnoyarsk, 660017, Russia
}

Received 09.09.2015, received in revised form 24.10.2015, accepted 04.11.2015

The new educational standards which reflect modern reality demand new understanding of the following functions of vocational training, such as adapt2able, informative, developing.

The competent teacher provides the students with the subject model of education, model of parity relations and social partnership, builds the educational process on the basis of three components which form unity and integrity: education, training and development.

The working people today proved to be in conditions when to find out the solution of a problem they need not only new knowledge from the sphere of sciences in accordance with the specialization of their work, but the ability to extract and apply new knowledge in their own practical activity.

Keywords: Lifelong learning, educational environment, educational standarts, interactive technologies, foreing language learning.

The article is written with the financial support of the European Commission within the Tempus IV programme (Project "Lifelong Language Learning University Centre Network for New Career Opportunities and Personal Development (UNICO)", № 544283-TEMPUS-1-2013-1-ES-TEMPUSJPHES).

DOI: 10.17516/1997-1370-2015-8-11-2212-2219.

Research area: pedagogy.

There exists a close connection between the recognition of the personally oriented value of education and the tendency to understand education as the continuous process which is going on during all human life. Education is capable not only to support up to the mark values of a society, but to enrich and develop them as well.

If we consider the purpose of education as development of a person who is meeting the requirements of a society in which he or she lives (what is reflected in connection between education and culture) then there is a strong requirement for a new paradigm of education: the education which is focused on development of personal self-respect, feeling of freedom, professional and common cultural competence. It demands radical change in content and organizational forms of the whole educational system, change of educational values as social and cultural phenomenon.

(C) Siberian Federal University. All rights reserved

* Corresponding author E-mail address: larisa-ajsner@yandex.ru 
However traditionally, the state policy in the sphere of education and science is formed in such a way that persons at the age from 1 year till 24 years are in the main focus if its attention. Such policy should cause both concern and bewilderment. It is a well-known fact that education is a basis of success of an individual, society and national economy as a whole. Besides, the tendency to pension age increase should force politicians and economists to seriously consider essential profit on investments into education of adult people. A starting point should be formation of such environment of training for adults in which they could believe that they can study and education will bring real advantage for them.

Having received higher education and having started the professional career a young person starts to understand what exactly has not been learnt during his or her school or university years and a young person starts to understand that it is necessary to continue education to improve professional skills or even get additional ones. But the more time passes from the moment of graduation from a higher educational establishment the more it is difficult for various reasons to continue education.

The general aim for all countries who signed the Bolognese declaration is to increase the role of lifelong learning, aspiration to enrich and extend model of European educational space all over the world. Each country develops its own way to perfect the level of national education systems and to create favorable conditions for different people to get training which corresponds their abilities, possibilities, interests and propensities.

Following the above mentioned idea the UK government in January, 2013 carried out the sociological research on lifelong learning ${ }^{1}$. The results of this research showed that education for people aged 35 years and above is necessary not only for job hunting but not to lose the existing job, to earn more; the research also showed the correlation between education and national tolerance and interest in political issues.

The modern educational policy of Russia is focused on creation of the all-Russian system of estimation of quality of education (RSEQE). Under the idea of quality of education in RSEQE Concept such type of an education system which reflects the degree of conformity of educational results and conditions of maintenance of educational process to standard requirements, social and personal expectations is understood.

RSEQE Concept assumes implementation of the following ideas:

- Increase in availability of getting quality education and security of citizens;

- Increase in the level of information awareness of people while decisionmaking on continuation of education;

- Maintenance of unity of educational space.

Thus, in a context of tasks in view, the system of evaluation of quality of education should be based on:

- "Realness" of requirements, norms and indicators of quality of education and their social and personal importance;

- Age-specific and psychological adequacy of procedure of indicators;

- Increase in the potential of an internal estimation, self-estimation of subjects of educational process in the conditions of lifelong learning;

- Ability to self-checking and selfestimation of an educational activity;

- Use of modern technologies, the tools providing objective results.

Reorientation of educational process of higher education establishments to estimation of educational results promotes introduction of modern educational technologies for formation 
in students the necessary competence, creation of testing funds which allow the teachers to evaluate formed competence (Aisner, 2015).

Social,economicandculturaltransformations in Russia essentially influence the expansion of functions of a foreign language as a subject. Expansion of the international cooperation, necessity of new business contacts and effective maintenance of already existing ones demand from experts, engineers, managers and scientists to know at least one foreign language as a means of communication. It changes accent in the field of foreign language learning: there is a transition from the concept to "study a foreign language forever" to the concept "to be capable and ready" to study a foreign language and culture for various purposes and educational contexts during all life.

It is possible to say that effective learning of a foreign language as the means of providing requirements of social and cultural activity assumes, first of all, ability independently, "through all life" to study a language, to support and fill up knowledge and abilities, to develop communicative and information culture. Thus, in the field of foreign language training there could be noticed the transition to productive educational technologies which are focused on independent educational activity of a student. In turn it defines perspective directions of language learning. Among which it is necessary to underline the following:

- Providing student with modern tools to define the level of the achievements in a foreign language learning;

- Further perfection of the knowledge and skills;

- Development and support of each person interests in studying of languages throughout all life.

The use of computer technologies in the process of foreign language training in different age groups promotes development of new educational and methodical teaching materials and application in educational process the new forms of the intermediate and final fisting. Training with the help of multimedia programmes is a basis of complex realisation of methodical, didactic, pedagogical and psychological principles. Implementation of the principle of the individual and differentiated approaches in training gives the chance to take into consideration the levels of language preparation and age age-specific features of students by means of preparing of tasks with various degree of complexity within the limits of one program. Thus, the principle of availability of tasks is provided and also individual work pace of a student is considered.

Information technologies in the course of foreign language training demand the active position of a student regardless of the age group and level of language knowledge. The given type of educational activity excludes possibility of passive perception of the information and promotes development of informative independence of students, formation of skills to independently accumulate knowledge and carry out research and focus on the streams of new information.

Modern ICT is a whole range of means of foreign language training: multimedia training programs ("Professor Higgins", "Oxford platinum", "English platinum", dictionaries (http://spravki.net/), a huge variety of the Internet resources are available - educational and authentic teaching materials on foreign languages, electronic versions of foreign newspapers and magazines (http://www.onlinenewspapers. com/), publications (http://www.washtimes. $\mathrm{com} /$ ), etc. There exists a great number of multimedia tutorials such as interactive courses "Tell me more", "English: the way to perfection", encyclopedias for children (for example: " Encyclopedia Britannica") etc. The materials are 
focused on improving reading, writing, listening, speaking skills, introduction and revision of grammar and are provided with tasks and exercises which allow students to study not only with the help of a teacher but without a teacher as well. In this connection it is necessary to notice that the computer, audio, video equipment is the basis, the purpose, the means of information and knowledge search for students. They are not end in themselves but serve, first of all, to solve particular practical problems.

Multimedia as a type of interactive technologies is a whole spectrum of information technologies using various program and means which implement information processing in a sound and visual type mode to promote the most effective influence on a user. Multimedia transfers sound, data and images via local, regional and global networks. Special programmes for real mode communication allow the teacher to organise teamwork of remote users with the program started on a local computer. The pictures, animation, photo, video, sound, text in the interactive operating mode create the integrated information environment in which any student of any age group is capable to find absolutely new possibilities for lifelong learning.

Application of multimedia in foreign language training in different age groups promotes the increase of an individualization of the educational process, deeper understanding of the subject.

For example, multimedia language class Rinel-Lingo is a set of special equipment, computers and the software, intended to provide involvement of 226 students simultaneously. The Class allows to use more sophisticated techniques to compare with traditional use of computers.

Another type of interactive technologies HiClass - the training complex which creates the dynamical educational environment by demonstration of materials from the teacher's computer to students' monitors in real time. The multimedia network combines studying and discussion, interactive communication of a student and a teacher, thus intensifying learning efficiency.

LTP (Language Teacher Partner) is used for interactive training to foreign languages and evaluation of the achieved results. The device contains the detailed grammatical directory and a tourist phrase book in 7 European languages; the device is equipped with the built-in TOEFL sample.

ICLE (Interactive Collaborative Learning Environment) gives the possibility to study foreign languages in three-dimensional environment in real time. ICLE integrates the three-dimensional environment technology of ear-phones developed for foreign language training of students with different levels. ICLE uses Multimedia computers, the training is carried out in four 3D levels (a hall, office, a sleeping room and a vestibule). Each level has a number of the three-dimensional models accompanied by English.

Development of training and supervising programs of high quality is a difficult time and effort consuming process which involves foreign language teachers, linguists and the methodologists and computer experts. Result of this activity - multimedia programs - should be used in foreign language lifelong learning.

Unlike isolated teaching programs the electronic textbook represents the collection of all basic theoretical and practical teaching materials. The textbook structure provides an entry-level course which is necessary for weak students, a basic course and an appendix. Depending on the form of training (an independent mode, on-line mode, videoconferences or everything combined) and the level of language knowledge a student either strictly follows the course of the textbook or works in accordance with the instructions of the teacher. Another advantage is in the capability 
of a student to choose the topics to study to cater the individual needs. With any form of training the testing tasks are intended for the open control and are carried out by a lifelong learner during limited time, on-line or independently. Within the frames of an electronic textbook, tasks designed for the independent work should by supplied with test type tasks with keys. Usually keys are shown only after the third attempt to answer and can be supplied by comments or references to the corresponding theoretical sections of the textbook. Creative tasks are checked by the teacher. In case of on-line mode there is no need to provide a student with keys. All tasks are checked by the teacher. The teacher checks the testing tasks made by a student by means of e-mail. Working in an independent mode a student can ask a teacher to provide a additional consultation by phone, for example. Thus an electronic textbook allows to better organise the students work and provides them with the minimum set of all necessary teaching materials that is especially actual for distance learning.

The Internet is attractive by several key positions. On the one hand, using the Internet as source of the considerable quantity of the information the teacher is able to save time searching the necessary modern authentic teaching material and concentrate on methodical work of processing of the text, sound, visual information. On the other hand, the Internet gives ample opportunities to create, to use of on-line teaching material, the teacher defines the purposes of a lesson structure, develops it, invents new types of activities according to specific goals and students' needs.

The tasks prepared with the help of the Internet can be made on-line (information search on the basis of the task developed by the teacher) or off-line (solving of crossword puzzles and other linguistic puzzles prepared by means of the Internet). On-line and off-line forms suggest the third category of tasks - students' design work (a linguistic Internet page, thematic posters and brochures). Among advantages of the design work creative potential of students, a problematic approach to a material, possibility of carrying out of research work, acquaintance with legal base of copying of materials from a network should be mentioned.

Thus the Internet promotes foreign language learning efficiency by means of increase in motivation of students, mastering of critical thinking skills of authentic texts and carrying out of research work in the Internet and language plunge in general. The mentioned teaching and learning features are especially important for lifelong learners.

Scientific and technological progress and global increase in the level of information acquisition of a society highly influences modern education. On the one hand, there is an increase of volume of the educational information and on the other - the obtained knowledge quickly becomes outdated. The modern society dictates necessity to obtain education throughout life that leads to occurrence in the educational process representatives of different age groups. New pedagogical and information technologies are urged to solve this problem.

The computer as a tutorial takes for a long time a leading place in educational process. Howevermoderninnovative technical possibilities allow to organise in a new mode the educational process, to make it more sated, creative and actual, thus the computer can be built-in not only in the structure of a classroom lesson, but also to organise out-of-class individual work or distant training at the expense of shifts of target audience and its age.

Ways of structuring of foreign language training by means of computer technologies depend completely on the motivations of a 
teacher. Defining the purposes, problems and possibilities of computer technologies usage at a lesson the teacher should bear in mind the following principle positions, namely:

- Preservation of mental and physical health of students;

- Formation in of elementary user skills students;

- The help to students in teaching material mastering on the basis of specially applied computer programs created solely for this purpose on foreign language learning.

For example, video-presentation as a type of means of distance learning allows to cooperate the different game-role, training forms modelling professional activity of a student individually or as a part of group training. Use of such kind of training, the role of the teacher in the educational process varies. At the initial stage the teacher supervises and gives the presentation plan, explains the sequence of actions and allocates specific speech examples which should be used in presentation of preparation and in the course of discussion as well.

The second stage provides the students with the opportunity to find authentic learning materials by means of the Internet. During the third stage the role of the teacher is reduced to supervision over how the student makes the presentation of the prepared material in a foreign language in front of the group, further becomes the direct participant of the discussion.

The education process should create conditions for active cognitive activity of each learner. If training to a foreign language is conducted in mixed groups with different language level of the teacher is deemed to the following problem solving activities:

a) adaptability problem, i.e. the organisation of learning activity in the way which allows to take into account all individual possibilities of each student;

b) Problem of optimisation of the educational process, i.e. maintenance of simultaneous work of all members of the group.

Both these problems could easily be solved by means of the computer. The teaching material could be mastered by students individually, with various degree of depth and completeness and succession.

It is necessary to mentioned such type of interactive technologies at training to foreign languages as videocourses. Videocourses provide the students with socio-cultural awareness: mimicry, gestures, the clothes and surrounding conditions. Besides, on the basis of these videocourses, the teacher can introduce in the educational process various role games and organise discussions, debates to revise the lexical material, for example.

The term interactive training is often mentioned in connection with information technologies, distance learning, with use of resources of the Internet. However, interactive training is the way of knowledge acquisition which is carried out in forms of joint activity, when all the participants of the educational process cooperate with each other, communicate with the purpose of common problem solving and model situations. Interactive training assumes the model of educational process which differs from usual logic: not from the theory to practice but from formation of new experience to its theoretical understanding through application. Application of interactive technologies in educational process forms the ability to think out of the ordinary, in a personal way to evaluate a situation and look for the ways out of it; to ground the positions; to develop different abilities, for example the ability to listen to other point of view.

The following ideas can be attributed to the forms and methods of interactive training: 
heuristic conversation, presentations, discussions, methods of "a round table" and of "business game", practical work contests together with discussions, role games, trainings, collective decisions of creative problems, a case-method.

The Brain storm technology stimulates creative activity of students and promotes development of speech skills. Participants of discussion are offered to state as many ways of the decision of a problem for the limited period of time. Such technology is perfectly applicable for discussion of different problem questions.

While using Unfinished statement the students are offered an unfinished statement that should be completed in the way defined by the teacher. The beginning of the sentences could be different and the students are supposed to finish the statements its any words, the first thought which come to mind. Statements begin rather vaguely, therefore leaving the students with practically unlimited possibilities to complete them.
In a context of lifelong learning the process of getting knowledge acquires other forms. On the one hand, knowledge represents the certain information on the world around. Feature of this information is that the students receive it not in the form of already ready system from the teacher but in the course of own activity. On the other hand, a student in the course of interaction with other students, the teacher acquires the system of the already tested (approved) ways of activity in relation to oneself, to society, to the whole world in general, acquires various search engines of knowledge.

Therefore knowledge received by a student is simultaneously the tool for their independent acquisition. Thus, the purpose of active training is a creation by the teacher of such conditions in which a student will find, get and design knowledge. It is basic difference between the purposes of active training and the purposes of a traditional education system during lifelong learning.

\footnotetext{
www.niace.org.uk
}

\section{References}

Aisner, L.U., Bershadskaya, S.V. \& Bogdan O.V. Portfolio as a means of evaluation of educational results. International Postal Conference "The Problems of agrarian science". Krasnoyarsk State Agrarian University, 2015, http://www.kgau.ru/new/all/konferenc/

Bogislavsky, M.V. (2006). Russian Education Reforms of XIX-XX as the Global Project. The Problems of Education, 3, 5-21.

Ivanchenko, T.U. (2013). Language Portfolio as Strategy of Lifelong foreign language learning. Young Scientist, 5, 704-707.

Osin, A.V. Multimedia in Education. Moscow, Rhythm, 2005, 320 p.

Volkov, A.E., Kusminov, Ya.I., Remorenko, I.M., Rudnik, B.L., Frumin, I.D. \& Yakobson, L.I. (2008). Russian Education - 2020. Model for Innovative Economy. The Problems of Education, 1, 32-65. 


\title{
Теоретические аспекты использования \\ интерактивных технологий \\ в процессе обучения иностранным языкам \\ в разных возрастных группах
}

\author{
Л.Ю. Айснер, С.В. Бершадская, О.В. Богдан \\ Красноярский государственный аграрный университет \\ Россия, 660017, Красноярск, ул. Ленина, 117
}

Новые образовательные стандарты, отражающие объективные условия современной реальности, требуют нового понимания функиий профессионального образования, таких как адаптационная, информационная, развивающая. Компетентный преподаватель обеспечивает субъектную модель образования, модель паритетных отношений и сочиального партнерства, строит образовательный прочесс на основе трех компонентов, образующих единство и целостность: воспитания, обучения и развития.

Специалисты сегодня оказались в условиях, когда для решения своих проблем им необходимы не только новые знания из сферы наук по своему профилю работы, но и способность их добывать и применять в собственной практике.

Ключевые слова: образование на протяжении всей жизни, образовательное пространство, образовательные стандарты, интерактивные технологии, обучение иностранным языкам.

Статья написана при финансовой поддержке гранта программы ТЕМПУС IV Европейского Союза (проект «Создание сети университетских языковых центров для профессионального и личностного развития человека в рамках парадигмы «образование в течение всей жизни», № 544283-TEMPUS-1-2013-1-ES-TEMPUS-JPHES).

Научная специиальность: 13.00.00 - педагогические науки. 